\title{
Anxiolytic-like Effect of Luma chequen Essential Oil: A Pilot Study
}

\author{
Paul Alan Arkin Alvarado-García',*, Marilú Roxana Soto-Vásquez ${ }^{2}$, Luis Enrique Rosales-Cerquin³ ${ }^{3}$ Demetrio \\ Rafael Jara-Aguilar ${ }^{2}$, Santiago M. Benites ${ }^{4}$
}

Paul Alan Arkin Alvarado-García ${ }^{1, *}$, Marilú Roxana Soto-Vásquez², Luis Enrique Rosales-Cerquin ${ }^{3}$, Demetrio Rafael Jara-Aguilar², Santiago M. Benites ${ }^{4}$

'Universidad Autónoma del Perú. Escuela de Psicología. Lima, Perú.

${ }^{2}$ Facultad de Farmacia y Bioquímica Universidad Nacional de Trujillo, Trujillo, PERÚ.

${ }^{3}$ Escuela de Medicina. Universidad César Vallejo, Trujillo, PERÚ.

${ }^{4}$ Universidad Autónoma del Perú. Lima, PERU.

\section{Correspondence}

Ms. Paúl Alan Arkin Alvarado García

Universidad Autónoma del Perú:

Panamericana Sur Km. 16.3, Villa EL

Salvador. Lima. PERÚ.

Phone no:0051-998435700

E-mail: palvaradog@autonoma.edu.pe

History

- Submission Date: 27-10-2021;

- Review completed: 12-11-2021;

- Accepted Date: 26-11-2021.

DOI : 10.5530/pj.2021.13.207

Article Available online

http://www.phcogj.com/v13/i6

Copyright

(C) 2021 Phcogj.Com. This is an openaccess article distributed under the terms of the Creative Commons Attribution 4.0 International license.

\begin{abstract}
Introduction: Essential oils are complex substances used widely extended in the form of aromatherapy or phytotherapy, some of them as agents to relieve anxiety and stress. In this sense this study was conducted to examine the anxiolytic-like effect of Luma chequen essential oil. Methods: The essential oil was extracted by steam distillation and the chemical composition was investigated by Gas chromatography with flame-ionization detection (GC-FID) and Gas chromatography-mass spectrometry (GC-MS). Moreover, a randomized, double blind, placebo-controlled trial was conducted, where 48 participants were divided into two groups, comprising a control group (CG) treated with placebo, and an experimental group (EG) treated with aromatherapy based on Luma chequen essential oil. The anxiety index was evaluated by State-Trait Anxiety Inventory (STAI). Measures were taken at two times: pretest and posttest. Results: The chemical analysis showed that $\alpha$-pinene was the main component (56.5\%). State and Trait anxiety scores showed a decrease in posttest study phase in comparison with pretest in experimental group compared to placebo ( $p<0.005$ for state anxiety and $p<0.05$ for trait anxiety). Cohen's d score was 0.84 in State anxiety, while it was 0.52 for Trait anxiety. Percentages of change showed reductions of anxiety variable ranging between $14.94 \%$ for State anxiety and $13.60 \%$ for Trait anxiety. Conclusions: These results suggest that aromatherapy based on essential oil of Luma chequen was moderately effective in improving anxiety.

Key words: Essential oil, Anxiety, Luma chequeen
\end{abstract}

\section{INTRODUCTION}

Different studies have consistently shown that anxiety is among the most prevalent health problems in the $21^{\text {st }}$ century and it is one of the most prevalent psychological problems during the COVID-19 pandemic ${ }^{1}$. The WHO Global Burden of Disease Study estimates that anxiety is one of the main causes of world disability ${ }^{2}$, because it is associated with chronic conditions such as migraine, gastrointestinal problems, heart disease, etc $^{3}$. It also negatively impacts the existential aspects of individuals such as work performance and social interactions ${ }^{4}$.

Pharmacological treatment usually employs benzodiazepines (BDZs) and antidepressants, nevertheless, BDZs produce side effects as lethargy, retrograde amnesia, drowsiness, dizziness, and vertigo $^{5}$, in addition, antidepressants can provoke weight gain, tachycardia, sexual dysfunction among others ${ }^{6}$, affecting clinical adherence. To this is added the fact that synthetic drugs produce other important drawbacks such as indiscriminate use, tolerance, and dependence ${ }^{7}$.

In this context, non-pharmaceutical treatment has received considerable attention ${ }^{8}$. In fact, investigations in herbal medicine have revealed a variety of medicinal plants may provide benefits in anxiety treatment ${ }^{9,10}$, highlighting the use of essential oils (EOs) as a useful alternative therapy to relieve anxiety ${ }^{11}$

EOs have been used traditionally from ancient times, these metabolites are usually highly complex mixtures of natural compounds, both polar and non-polar ${ }^{12}$, and are defined by The International
Organization for Standardization (ISO) (ISO/ D1S9235.2), as products made by distillation with either water or steam or by mechanical processing or by dry distillation ${ }^{13}$. EOs are obtained from different parts of aromatic plants, although at present new sources of these secondary metabolites are examined, such as food and vegetal wastes ${ }^{14}$.

Some researchers have found that aroma inhalation reduces anxiety ${ }^{15}$. In fact, Lavandula angustifolia (lavender), Rosa damascene (rose), Citrus sinensis (orange), Citrus bergamia (bergamot), Salvia sclarea (clary sage), Matricaria recutita (Chamomile) and Pelargonium species EOs can lead to decrease levels of anxiety ${ }^{16,17}$.

In the clinical context, a study confirmed the effectiveness of geranium EOs to manage anxiety of nulliparous women during labor ${ }^{18}$. Likewise, an investigation found that aromatherapy is a cost-effective method that can reduce anxiety in hospitalized patients with acute coronary syndrome $^{19}$, as well as in preoperative anxiety ${ }^{20}$.

Luma chequen is a species of flowering shrub in the family Myrtaceae, growing between 2500 to 4000 $m$ elevation, native to the South American Andes between Perú, Bolivia, Chile, and Argentina ${ }^{21}$ Its leaves and twigs are traditionally used for the treatment of gastrointestinal and respiratory disorders, post-parturition infections, insomnia and anxiety $^{22}$. Luma chequen essential oil is marketed and use in Peru for calming and balancing emotions due to their components such as linalool, limonene among others with anxiolytic properties ${ }^{23-25}$. Thus, the present investigation was conducted to evaluate whether aromatherapy based on Luma chequen essential oil can reduce anxiety levels. 


\section{MATERIAL AND METHODS}

\section{Plant material}

The fresh leaves of Luma chequen were collected from Yungay village at 2,458 meters elevation, located in Yungay district, Ancash Region, Peru. The sample collection was conducted in the month of August 2019. Voucher specimens were prepared and identified by Segundo Leiva Gonzales, Biol, and deposited at the Herbarium Antenor Orrego (HAO) of Antenor Orrego University.

\section{Essential oils extraction}

The freshly collected leaves were washed with distilled water to remove dust. Then, samples were dried using a forced air circulation stove at a temperature of $40^{\circ} \mathrm{C}$ for $24 \mathrm{~h}$. Subsequently leaves were milled, and the powdered plant material $(100 \mathrm{~g})$ and $1000 \mathrm{ml}$ distilled water were placed in a round-bottomed flask and connected to a Clevenger-type apparatus. Hydrodistillation was completed after 3 hours of boiling. Finally, the oil was dried over anhydrous sodium sulfate and stored in a refrigerator in amber glass vials at $4{ }^{\circ} \mathrm{C}$ for further use in experiments ${ }^{26}$.

\section{Determination of essential oil composition}

The essential oil was analyzed by Gas chromatography with flameionization detection (GC-FID) and Gas chromatography-mass spectrometry (GC-MS), using two fused silica capillary columns with two different stationary phases (SPB-1 and SupelcoWax $10,30 \mathrm{~m}$ x $0.2 \mathrm{~mm}, 0.20 \mu \mathrm{m})$. GC was performed in a Hewlett Packard 6890 gas chromatograph with a flame ionization detector (FID), using the following conditions: oven temperature programmed at $70^{\circ}-220^{\circ} \mathrm{C}$ $\left(3^{\circ} \mathrm{C} / \mathrm{min}\right), 220^{\circ} \mathrm{C}(15 \mathrm{~min})$; injector temperature: $250^{\circ} \mathrm{C}$; detector temperature: $250^{\circ} \mathrm{C}$; split ratio 1:40; carrier gas, helium. GC-MS was carried out using a Hewlett-Packard 6890 series gas chromatograph coupled with a mass selective detector Hewlett Packard MSD 5972, using the same analytical conditions as above; interface temperature: $250^{\circ} \mathrm{C}$; MS source temperature: $230^{\circ} \mathrm{C}$; EI mode $70 \mathrm{eV}$. Finally, the identification of essential oil constituents was based on comparing their GC retention indices (RI) and mass spectra with literature data and with those in the NIST 2011 mass spectra library as well as Wiley library ${ }^{23,26}$.

\section{Study design and sample}

An experimental study with measures at pretest-posttest was conducted. 48 participants were divided into two groups of 24 participants, comprising a control group (CG) treated with placebo, which was a non-essential oil-based scented shampoo ${ }^{27}$, and an experimental group (EG) treated with aromatherapy based on $L$. chequen essential oil.

\section{Study procedure}

A free aromatherapy course was offered through social media to recruit participants. 61 people were enrolled and 48 took part in this investigation between November 2019 and December 2019. Inclusion criteria included male and female participants between the ages of 18-45 and they were required to have a State-Trait Anxiety Inventory score of greater than 20 in both scales; meanwhile exclusion criteria were participants with previous practice of alternative therapies such as meditation, tai chi or yoga, psychiatric treatment, and pregnancy. 24 participants for each group were randomized by a person not involved in the study by utilization of a random number table. After CG and EG were formed, a basic questionnaire consisted of socialdemographic characteristics was applied to characterize participants. After that, an anxiety self-report instrument was administered (pretest) and filled by all participants. Two schedules were disposed for each intervention group (one in the morning and one in the afternoon) to prevent them from influencing each other. The $L$. chequen essential oil and placebo were placed every session in identical amber glass vials marked with the code A and B, respectively. It was used as placebo a commercial shampoo (Johnson's ${ }^{\star}$ baby shampoo, free from sulfates and parabens). Both, participants, and researchers did not know of the code meaning. In addition, one researcher oversaw the experimental group, and another was in charge of the control group. Both were held incommunicado throughout the experiment to minimize bias; besides, they wore face masks ( $\left.3 \mathrm{M}^{\mathrm{TM}} \mathrm{N} 95\right)$, according to the methodology used by Ndao et al..$^{27}$

A Psychotherapy room (4x4 m size) of Integral Psychotherapy Center was used for experiments. Windows were closed hermetically during stimulus administration and participants sat in ergonomic chairs forming a circle. Five essential oil diffusers with $200 \mathrm{~mL}$ capacity were used for administrating oil and placebo by inhalation. These were placed one in each corner of therapy room and one in the middle of the circle of participants. The essential oil dose required to saturate the experimental room was 4 drops of $2 \%$ essential oil $=0.2 \mathrm{~mL}$; and placebo dose required was also 4 drops. All groups had 30 minutes intervention sessions from Monday to Saturday for two weeks (12 sessions). Next, an anxiety self-report instrument was administered (posttest) to the 44 participants who remained to the end of the study (four participants, one in EG and three in CG, were lost) (Fig. 1). All participants were informed about the investigation program goals and signed a consent form in which confidentiality and anonymity were guaranteed. The study protocol was approved by Institutional Review Board (IRB). Besides, this investigation was performed in accordance with the Declaration of Helsinki.

\section{Instruments}

Anxiety was evaluated, using the State-Trait Anxiety Inventory (STAI), which consists of two self-report scales measuring two distinct types of anxiety: state (actual levels of intensity and anxiety states) and trait (selects individuals who vary in their tendency to react to psychological stress with varying degrees of intensity). Both scales consist of 20 statements and respondents rate the intensity of their feelings about each at that moment from 1 (not at all) to 4 (very much so). The part that regards trait describes how the subjects generally feel, while the part that regards state describes how they feel at a given moment ${ }^{28,29}$. Validations and reliability coefficients for local population were found in a previous study Inventory was validated for local population in a previous study ${ }^{30}$.

\section{Data Analysis}

Data were presented as mean \pm standard deviation (SD). Independent samples $t$ Test was used to determine significant differences between CG and EG, while Paired Samples $t$ Test was used to determine significant differences between the study phases. These tests were chosen because data conformed to the normal distribution. Cohen's D and Percentage Change were calculated between pretest and posttest scores. All statistical analysis was performed using SPSS v.25.0 (IBM Corp., Armonk, NY, USA).

\section{RESULTS}

Chemical composition of the essential oil of Luma chequen is shown in Table 1, where 31 components were identified, representing 96.1\% (area percent) of total oil content, among which $\alpha$-pinene $(56.5 \%), 1,8$-cineole (8.5\%), linalool (6.8\%), $\beta$-pinene (6.4\%), isobutyl isobutyrate (1.9\%), $\alpha$-Terpineol (1.8\%), p-cymene (1.2\%) and camphene (1.1\%) were the major constituents.

Table 2 presents socio-demographic and clinical data of analyzed participants, where 19 were male and 25 were female. CG was formed by $9(43 \%)$ male and $12(57 \%)$ female, while EG was formed by $10(44 \%)$ male and 13(56\%) female. Most participants were between 25-35 years 
Table 1: Main chemical constituents (\%) of the essential oils of Luma chequeen.

\begin{tabular}{|c|c|c|}
\hline Components* & RI & $\%$ \\
\hline Isobutyl isobutyrate & 924 & 1.9 \\
\hline a-Thujene & 927 & 0.1 \\
\hline a-Pinene & 932 & 56.5 \\
\hline Camphene & 945 & 1.1 \\
\hline$\beta$-Pinene & 968 & 6.4 \\
\hline p-Cymene & 994 & 1.2 \\
\hline 1,8-Cineole & 1018 & $8.5^{\square}$ \\
\hline Limonene & 1025 & $5.8^{\square}$ \\
\hline cis-Linalool oxide & 1066 & 0.1 \\
\hline Linalool & 1084 & 6.8 \\
\hline Fenchol & 1101 & 0.2 \\
\hline Campholenal & 1115 & 0.1 \\
\hline Pinocarveol & 1120 & 0.2 \\
\hline Cis-verbenol & 1129 & 0.6 \\
\hline Pinocarvone & 1136 & 0.1 \\
\hline Borneol & 1148 & 0.3 \\
\hline Terpinen-4-ol & 1160 & 0.3 \\
\hline Myrtenal & 1171 & 0.1 \\
\hline$\alpha$-Terpineol & 1182 & 1.8 \\
\hline Verbenone & 1194 & 0.2 \\
\hline$\beta$-Elemene & 1215 & 0.1 \\
\hline Geraniol & 1229 & 0.4 \\
\hline Thymol & 1273 & 0.2 \\
\hline Menthone & 1335 & $t^{\otimes}$ \\
\hline$\beta$-caryophyllene & 1410 & 0.2 \\
\hline Aromadendren & 1432 & 0.3 \\
\hline Allo-aromadendrene & 1451 & $t^{\otimes}$ \\
\hline$\beta$-selinene & 1476 & 0.8 \\
\hline a-muurolene & 1494 & 0.4 \\
\hline$\delta$-cadinene & 1510 & 0.3 \\
\hline $\mathrm{Nd}$ & 1559 & 0.2 \\
\hline Globulol & 1571 & 0.9 \\
\hline Total identified (\%) & & 96.1 \\
\hline
\end{tabular}

$\mathrm{RI}$, Retention index; $\mathrm{t}=$ traces $(<0.1 \%) ;-$, not detected.

Table 2: Socio-demographic and clinical data of participants.

\begin{tabular}{lccc}
\hline Socio-demographic data & CG & EG & Total \\
Gender & & & \\
Male & $9(43 \%)$ & $10(44 \%)$ & $19(43 \%)$ \\
Female & $12(57 \%)$ & $13(56 \%)$ & $25(57 \%)$ \\
Age(yr) & & & \\
$18-24$ & $4(19 \%)$ & $5(22 \%)$ & $9(21 \%)$ \\
$25-35$ & $14(67 \%)$ & $16(69 \%)$ & $30(68 \%)$ \\
$36-45$ & $3(14 \%)$ & $2(9 \%)$ & $5(11 \%)$ \\
Level of education & & & \\
High school & $1(5 \%)$ & $2(9 \%)$ & $3(7 \%)$ \\
Undergraduate & $9(43 \%)$ & $10(44 \%)$ & $19(43 \%)$ \\
Graduate & $7(33 \%)$ & $8(34 \%)$ & $15(34 \%)$ \\
Postgraduate & $4(19 \%)$ & $3(13 \%)$ & $7(16 \%)$ \\
Marital status & & & \\
Married & $8(38 \%)$ & $10(44 \%)$ & $18(41 \%)$ \\
Unmarried & $10(48 \%)$ & $9(39 \%)$ & $19(43 \%)$ \\
Divorced & $2(9 \%)$ & $3(13 \%)$ & $5(11 \%)$ \\
Widowed & $1(5 \%)$ & $1(4 \%)$ & $2(5 \%)$ \\
Anxiety treatment provided & & & \\
Psychological & $5(24 \%)$ & $6(26 \%)$ & $11(25 \%)$ \\
Pharmacological & $0(0 \%)$ & $0(0 \%)$ & $0(0 \%)$ \\
None & $16(76 \%)$ & $17(74 \%)$ & $33(75 \%)$ \\
& & &
\end{tabular}

old ( $\mathrm{n}=30 ; 68 \%)$, followed by the participants between $18-24$ years old $(n=9 ; 21 \%)$; and the rest between $36-45$ years old $(n=5 ; 11 \%) .3$ people (7\%) attended to high school, $19(43 \%)$ were undergraduate students, 15(34\%) were graduated and only $7(16 \%)$ were postgraduate. In relation to their marital status, 19(43\%) were unmarried, 18 (41\%) were married, 5 (11\%) were divorced and 2 participants were widowed. Majority of participants never attended a treatment $(n=33 ; 75 \%)$, $11(25 \%)$ attended a psychological treatment and no one attended a psychiatrist for pharmacological treatment. Finally, both CG and EG were constituted by same average number of participants by variable.

Table 3 shows the mean score and SDs for anxiety based on STAI, where EG does not present differences in pretest scores in comparison with CG ( $>0.05$ for state and trait anxiety); however, differences are shown in posttest scores ( $\mathrm{p}<0.05$ for state anxiety and $\mathrm{p}<0.05$ for trait anxiety). Besides, anxiety scores show a decrease in posttest study phase (32.17 and 28.42 for State and Trait anxiety respectively) in comparison with pretest (37.82 and 32.79 for State and Trait anxiety respectively) in experimental group $(\mathrm{p}<0.005$ for state anxiety and $\mathrm{p}<0.05$ for trait anxiety). These results show a change in STAI scores after the intervention. Meanwhile CG show a slight increase in posttest scores in comparison with pretest scores, but it does not show statistically significant differences $(\mathrm{p}>0.05)$.

Regarding the amount of change in the mean scores at posttest, it is observed that all Cohen's $d$ scores are over 0.50 and less than $1(\mathrm{~d}=0.84$ for state anxiety and $\mathrm{d}=0.52$ for trait anxiety). These scores indicate a medium size effect, suggesting that aromatherapy was moderately effective in improving anxiety. Finally, percentages of change between pretest and posttest measures show reduction of $14.94 \%$ for State anxiety and $13.60 \%$ for Trait anxiety. All these results show a decrease in anxiety scores (Table 4 ).

\section{DISCUSSION}

The chemical analysis of $L$. chequen essential oil showed that $\alpha$-pinene, 1,8 -cineole, linalool and $\beta$-pinene are the main components. This agrees with data from other investigations where these are also the major constituents ${ }^{22,23,26}$; however, another research study found D-limonene, eucalyptol and $\alpha$-pinene as the main components, but this last one presented lower values in comparison with our investigation ${ }^{31}$. This may be due to the difference of collection time, in our case and the rest of investigations with the same results, collection was done in spring while in the latter research study collection was done in fall. In fact, content of monoterpenes is more abundant in spring than in fall ${ }^{32}$. Although studies that involve the geographical variation are needed, because Andean countries like ours have different altitudinal floors.

Regarding socio-demographic and clinical data of participants, the majority were young adults and adults with university studies as well with no pharmacological treatment. This is in concordance with a previous study conducted by our research team, where participants were demographically similar ${ }^{33}$. This point constitutes one of the limitations because only few participants belonged to the least educated population and our study does not show how these therapies can work in a different population. To this is added the fact that participant number is insufficient hence results cannot be generalized. Another limitation is that due to homogeneity of the sample, correlations between sociodemographic and clinical data with anxiety scores are not displayed. It is important to mention that in the Peruvian context, the main provider of CAM therapies is Essalud, a type of national health insurance, which covers only the salaried population. Their services are not well known by general population, nor can the low income population afford $\mathrm{it}^{34}$. As a matter of fact, some studies affirm that most educated population is more likely to be interested in CAM therapies ${ }^{35}$.

Clinical evidence affirms that EOs can help lower preoperative anxiety $^{36}$, dental patient anxiety ${ }^{37}$, as well as anxiety status during 
Table 3: Group differences of anxiety variable according to State-Trait Anxiety Inventory (STAI).

\begin{tabular}{lccccc}
\multicolumn{1}{r}{ Groups } & \multicolumn{2}{c}{ Pretest } & \multicolumn{2}{c}{ Posttest } & \multirow{2}{*}{ p-Value } \\
\cline { 2 - 4 } & Mean & SD & Mean & SD & \\
\hline CG & & & & & \\
State Anxiety & 37.63 & \pm 6.61 & 37.71 & \pm 7.14 & 0.956 \\
Trait Anxiety & 32.33 & \pm 6.53 & 32.50 & \pm 7.05 & 0.934 \\
EG & & & & & \\
State Anxiety & 37.82 & \pm 6.21 & 32.17 & \pm 6.05 & $0.001^{*}$ \\
p-value & 0.911 & & $0.006^{*}$ & & \\
Trait Anxiety & 32.79 & \pm 6.49 & 28.42 & \pm 7.21 & $0.042^{*}$ \\
p-value & 0.808 & & $0.047^{*}$ & &
\end{tabular}

${ }^{*} \mathrm{p}<0.05$

${ }^{a} \mathrm{p}$-value is calculated by Independent samples $\mathrm{t}$ Test between groups ${ }^{b} p$-value is calculated by Paired samples t Test between study phases.

Table 4: Cohen's $\boldsymbol{d}$ and pretest-posttest percentages of change in intervention groups.

\begin{tabular}{lcc}
\hline Group & Cohen's d Postest & $\begin{array}{c}\text { \% of change } \\
\text { Pretest-Postest }\end{array}$ \\
\hline EG & 0.84 & -14.94 \\
State Anxiety & 0.52 & -13.60 \\
Trait Anxiety & &
\end{tabular}

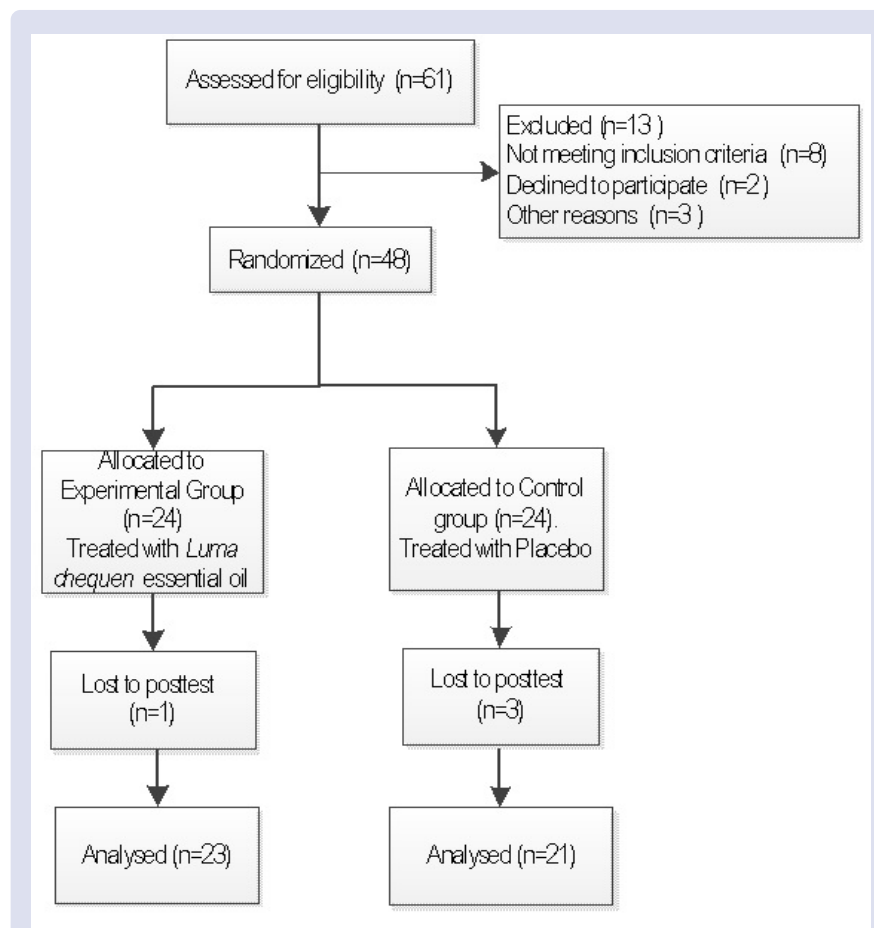

Figure 1: Flowchart of the study.

labor in nulliparous women ${ }^{38}$. In fact, findings confirm that using EOs in aromatherapy can diminish anxiety levels ${ }^{39}$. These outcomes agree with our findings where participants in EG showed a decrease in anxiety scores after intervention. Indeed, state and trait anxiety scores exhibited a medium size effect, suggesting that aromatherapy based on EOs of $L$. chequen was moderately effective in improving anxiety. Although there was a non-significant difference, the percentage of change for state anxiety was a little greater than trait anxiety. This is in accordance with other studies where EOs were more effective in reducing state anxiety ${ }^{40,42}$. It is appropriate to remark that state anxiety is related to temporary situations that changes every moment and when disappear, the individual no longer experience anxiety; instead, trait anxiety is related to particular and permanent personality features of individuals ${ }^{42}$. Nevertheless, the CG showed a little increase of state and trait anxiety scores after intervention with placebo, finding a nonsignificant difference. This is due to the commercial shampoo used in this group which reports no therapeutic effects, in this sense, natural aromas are superior to their synthetic counterparts since cannot imitate the EO's healing qualities yet ${ }^{43}$.

On the other hand, the anxiolytic-like effect may be attributed to a-pinene, the main component. In this sense daily inhalation of a-pinene can diminish stress and anxiety ${ }^{44}$. This constituent may have a potent action at the benzodiazepine (BZD) site of GABA receptors $^{45}$. In the same way, 1,8-Cineole has a similar effect to midazolam, also interacting at the $\mathrm{BZD}$ site on the $\mathrm{GABA}_{\mathrm{A}}$ receptor, producing anxiolysis ${ }^{46}$.

Nevertheless, other components present in the L. chequen EOs, such as limonene and linalool may exert an anxiolytic effect similar to that seen with diazepam. In the case of limonene, this monoterpene enhances $\mathrm{A} 2 \mathrm{~A}$ receptor activation and, consequently, induces GABA release and anti-anxiety activity ${ }^{25}$. Meanwhile linalool, one of the most investigated odorant molecules, has an antagonistic action on glutamatergic receptors such as $\mathrm{N}$-methyl-D-aspartate receptors (NMDARs) which may explain its sedative effect ${ }^{47,48}$. In addition, investigations confirm the capacity of EOs to influence significantly the Hypothalamic Pituitary Adrenal (HPA) axis, implicated in the pathogenesis of psychiatric disorders, including anxiety disorders, by decreasing glucocorticoid levels producing a calming effect; in fact, EOs also interact with a variety of central nervous system receptors implicated in the serotonergic and DAergic systems ${ }^{49}$.

It is known that the EOs main constituents play a major role in its therapeutic activities, nevertheless, according to evidence the anxiolytic effect of EOs could also be the result of the synergistic effects of its constituents $^{50}$. Indeed, Further studies are needed, such as structureactivity studies to determine the detailed mechanisms of action. In addition, there is a need to evaluate the biochemical parameters related to anxiety to determine more accurately the anxiolytic effect of essential oils, as well as to study the synergistic relationships between the EOs components.

\section{CONCLUSION}

Aromatherapy based on essential oil of Luma chequen, may be considered an alternative treatment option to counteract mild and moderate anxiety states.

\section{CONFLICTS OF INTEREST}

All authors have no conflicts of interest to declare.I

\section{REFERENCES}

1. Salari N, Hosseinian-Far A, Jalali R, Vaisi-Raygani A, Rasoulpoor S, Mohammadi M, Rasoulporr S, Khaledi-Paveh B. Prevalence of stress, anxiety, depression among the general population during the COVID-19 pandemic: a systematic review and meta-analysis. Glob Health. 2020; 16:1-11.

2. Ivandic I, Kamenov K, Rojas D, Cerón G, Nowak D, Sabariego C. Determinants of work performance in workers with depression and anxiety: a cross-sectional study. Int J Environ Res Public Health. 2017;14: E466.

3. Swift P, Cyhlarova E, Goldie I. Living with anxiety: understanding the role and impact of anxiety in our lives. 1st edition. London: Mental Health Foundation; 2014

4. McCarthy JM, Trougakos JP, Cheng BH. Are anxious workers less productive workers? It depends on the quality of social exchange. $J$ Appl Psychol. 2016; 101: 279-291. 
5. Nash JR, Nutt DJ. Pharmacotherapy of anxiety. Handb Exp Pharmacol.2005; 169:469-501.

6. Santarsieri D, Schwartz TL. Antidepressant efficacy and sideeffect burden: A quick guide for clinicians. Drugs Context. 2015;4: 1-12.

7. Da Silva CJ, Da Conceição RM, Alves FR, Dos Santos SS, Da Silva MT, Lima RP. Prevalence in the Use of Anxiolytics Among Nursing Professionals: an Integrative Review. IJPRR.2020; 3: 34.

8. Zaghari M, Tafreshi M, Rasouli A, Tabatabaee E, Golmakani Mortazavi $\mathrm{H}$. Utilization of complementary and alternative medicine in nursing with emphasis on the touch therapy. J North Khorasan Univ Med Sci. $2014 ; 6: 207 e 213$.

9. Sarris J, Mclntyre E, Camfield DA. Plant-based medicines for anxiety disorders, part 1: a review of preclinical studies. CNS Drugs. 2013; 7:207-219.

10. Sarris J, Mclntyre E, Camfield DA. Plant-based medicines for anxiety disorders, part 2: a review of clinical studies with supporting preclinical evidence. CNS Drugs. 2013; 27:301-319.

11. Ayaz M, Sadiq A, Junaid M, Ullah F, Subhan F, Ahmed J. Neuroprotective and Anti-Aging Potentials of Essential Oils from Aromatic and Medicinal Plants. Aging Neurosci. 2017; 9:168.

12. Macwan SR, Dabhi BK, Aparnathi KD, Prajapati JB. Essential oils of herbs and spices: Their antimicrobial activity and application in preservation of foods. Int J Curr Microbiol Appl Sci. 2016; 5:885-901.

13. Nazzaro F, Fratianni F, Coppola R, De Feo V. ssential Oils and Antifungal Activity. Pharmaceuticals. 2017; 10:86.

14. Fengfeng W, Yamei J, Xueming $X, N a$ Y. Electrofluidic pretreatment for enhancing essential oil extraction from citrus fruit peel waste. J Clean Prod. 2017, 159: 85-94.

15. Fradelos $E$, Komini $A$. The use of essential oils as a complementary treatment for anxiety. Am J Nurs Scie. 2015; 4:1-5.

16. López V, Nielsen B, Solas M, Ramírez MJ, Jäger AK. Exploring pharmacological mechanisms of lavender (Lavandula angustifolia) essential oil on central nervous system targets. Front. Pharmacol. $2017 ; 8: 280$

17. Dias P, Pedro L, Pereira OR, Sousa MJ. Aromatherapy in the Control of Stress and Anxiety. Altern Integr Med. 2017; 6:4.

18. Fakari FR, Tabatabaeichehr M, Kamali H, Fakari FR, Naseri M, Effect of inhalation of aroma of geranium essence on anxiety and physiological parameters during first stage of labor in nulliparous women: a randomized clinical trial. J Caring Sci. 2015; 4: 135.

19. Nematollahi MR, Bazeli J, Moghaddam MB, Aalami H. Effect of aromatherapy on anxiety in patients with acute coronary syndrome hospitalized in cardiac care unit. Bali Med J. 2017; 6:331-336.

20. Stea S, Beraudi A, De Pasquale D. Essential oils for complementary treatment of surgical patients: state of the art. Evid Based Complement Alternat Med. 2014; 2014:726341.

21. Torres-Chati J, León-Quispe J, Tomas-Chota G. Actividad antibacteriana y antifúngica de extractos de hojas de Luma chequen (Molina) A. Gray "arrayán" frente a patógenos de origen clínico. Rev Soc Ven Microbiol. 2017; 37:10-16.

22. Gonçalves MJ, Cavaleiro C, Proença da Cunha A, Salgueiro LR. Chemical Composition and Antimicrobial Activity of the Commercially Available Oil of Luma chequen (Molina) A. Gray. J Essent Oil Res. 2014; 18:108-110

23. Vallverdú C, Vila R, Tomi F, Carhuapoma M, Cassanova J, Cañigueral $\mathrm{S}$. Composition of the essential oil from leaves and twigs of Luma chequen. Flavour Fragr J. 2006; 21: 241-243.

24. Harada H, Kashiwadani H, Kanmura Y, Kuwaki T. Linalool Odor-Induced Anxiolytic Effects in Mice. Front Behav Neurosci. 2018; 12: 241.

25. Song Y, Seo S, Lamichhane S, Seo J, Hong JT, Cha HJ, Yun J. Limonene has anti-anxiety activity via adenosine A2A receptormediated regulation of dopaminergic and GABAergic neuronal function in the striatum. Phytomedicine. 2021; 83:153474.
26. Carhuapoma M, Bonilla P, Suárez S, Vila R, López S. Estudio de la composición química y actividad antioxidante del aceite esencial de Luma chequen (Molina) A. Gray "arrayam". Cien Invest. 2005;8:7379 .

27. Ndao DH, Ladas EJ, Cheng B, Sands SA, Snyder KT, Garvin JH, Kelly KM. Inhalation aromatherapy in children and adolescents undergoing stem cell infusion: results of a placebo-controlled double-blind trial. Psychooncology.2012; 21:247-254

28. Kutlu AK, Yilmaz E, Çeçen D. Effects of aroma inhalation on examination anxiety. Teach Learn Nurs.2008; 3:125-130.

29. Hu PH, Peng YC, Lin YT, Chang CS, Ou MC. Aromatherapy for reducing colonoscopy related procedural anxiety and physiological parameters: a randomized controlled study. Hepatogastroenterology. 2010; 57:1082-1086.

30. Soto-Vásquez MR, Alvarado-García PAA. Aromaterapia a base de aceite esencial de "satureja brevicalyx" "inka muña" y meditación mindfulness en el tratamiento de la ansiedad. Med Nat.2016;10:47-52.

31. Ruiz C, Díaz C, Rojas R. Composición química de 10 plantas aromáticas peruanas. Rev Soc Quím Perú. 2015; 281:81-94.

32. Nerg A, Kainulainen P, Vuorinen M, Hanso M, Holopainen JK, Kurkela $T$, Seasonal and geographical variation of terpenes, resin acids and total phenolics in nursery grown seedlings of Scots pine (Pinus sylvestris L.). New Phytol.1994;128:703-713.

33. Soto-Vásquez MR, Alvarado-García PAA. Aromatherapy with two essential oils from Satureja genre and mindfulness meditation to reduce anxiety in humans. J. Tradit Complement Med. 2017; 7:121-125.

34. Lujan-Carpio E, Lizarraga-Castañeda Z, Mayor-Vega A, MedranoCanchari K, Medina-Salazar H, Goicochea-Lugo S. El servicio de Medicina complementaria de EsSalud, una alternativa en el sistema de salud peruano. Rev Med Hered. 2014; 25:105-106.

35. Hawk C, Ndetan H, Evans Jr MW. Potential role of complementary and alternative health care providers in chronic disease prevention and health promotion: an analysis of National Health Interview Survey data. Prev Med. 2012; 54:18-22.

36. Wotman, M., Levinger, J., Leung, L., Kallush, A., Mauer, E., Kacker, A., 2017.The Efficacy of Lavender Aromatherapy in Reducing Preoperative Anxiety in Ambulatory Surgery Patients Undergoing Procedures in General Otolaryngology. Laryngoscope. Investig. Otolaryngol. 2,437-441

37. Zabirunnisa M, Gadagi JS, Gadde P, Myla N, Koneru J, Thatimatla C. Dental patient anxiety: Possible deal with Lavender fragrance. J Res Pharm Pract. 2014; 3:100-103.

38. Mirzaei F, Keshtgar S, Kaviani M, Rajaeifard AR. The Effect of Lavender Essence Smelling during Labor on Cortisol and Serotonin Plasma Levels and Anxiety Reduction in Nulliparous Women. J Kerman Univ Med Sci. 2009;16: 245-254.

39. Ali B, Al-Wabel NA Shams S, Ahmad A, Khan SA, Anwar F. Essentia oils used in aromatherapy: A systemic review. Asian Pac J Trop Biomed. 2015; 5:601-611.

40. Barati F, Nasiri A, Akbari N, Sharifzadeh G. The Effect of Aromatherapy on Anxiety in Patients. Nephrourol Mon. 2016;8: e38347.

41. Kavurmaci M, Küçükoğlu S, Tan M, Effectiveness of aromatherapy in reducing test anxiety among nursing students. IJTK. 2015; 1:52-56.

42. Ursache A, Raver CC.Trait and State Anxiety: Relations to Executive Functioning in an at Risk Sample. Cogn. Emot. 2014;28: 845-855.

43. Cavanaugh, J.L. Examining the differential effects of natural and synthetic aromas of lavender and peppermint on cognition modo and subjective worload. [dissertation]. Denver: University of Colorado; 2013.

44. Kasuya H, Hata E, Satou T, Yoshikawa M, Hayashi S, Masuo Y, Koike K. Effect on emotional behavior and stress by inhalation of the essential oil from Chamaecyparis obtuse. Nat Prod Commun. 2013 8:515-518. 
45. Yang H, Woo J, Pae AN,Um MY, Cho N, Park KD, Yoon M, Kim J. Lee C.J. Cho S. a-Pinene, a major constituent of pine tree oils, enhances non-rapid eye movement sleep in mice through GABAAbenzodiazepine receptors. Mol Pharmacol. 2016; 90:530-539.

46. Ceremuga TE, McClellan CB, Green XC, Heber BE, Jolly ML, Malone TB, Schaaf, JL, Isaacs AP. Investigation of the Anxiolytic and Antidepressant Effects of Eucalyptol (1,8-Cineole), a Compound From Eucalyptus, in the Adult Male Sprague-Dawley Rat. AANA Journal. 2017; 85:277-284.

47. Guzmán-Gutierrez SL, Gómez-Cansino R, García-Zebadúa JC, Jiménez-Pérez NC, Reyes-Chilpa R. Antidepressant activity of Litsea glaucescens essential oil: Identification of $\alpha$-pinene and linalool as active principles. J Ethnopharmacol. 2012; 143:673-679.

48. Aprostosoaie AC, Hăncianu M, Costache I, Miron A. Linalool: a review on a key odorant molecule with valuable biological properties. Flavour Fragr.2014; 29:193-219.

49. Lizarraga-Valderrama LR. Effects of essential oils on central nervous system: Focus on mental health. Phytother Res.2020; 35:657-679.

50. Okano S, Honda Y, Kodama, Kimura M. The Effects of Frankincense Essential Oil on Stress in Rats. J Oleo Sci.2019; 68:1003-1009.

\section{GRAPHICAL ABSTRACT}

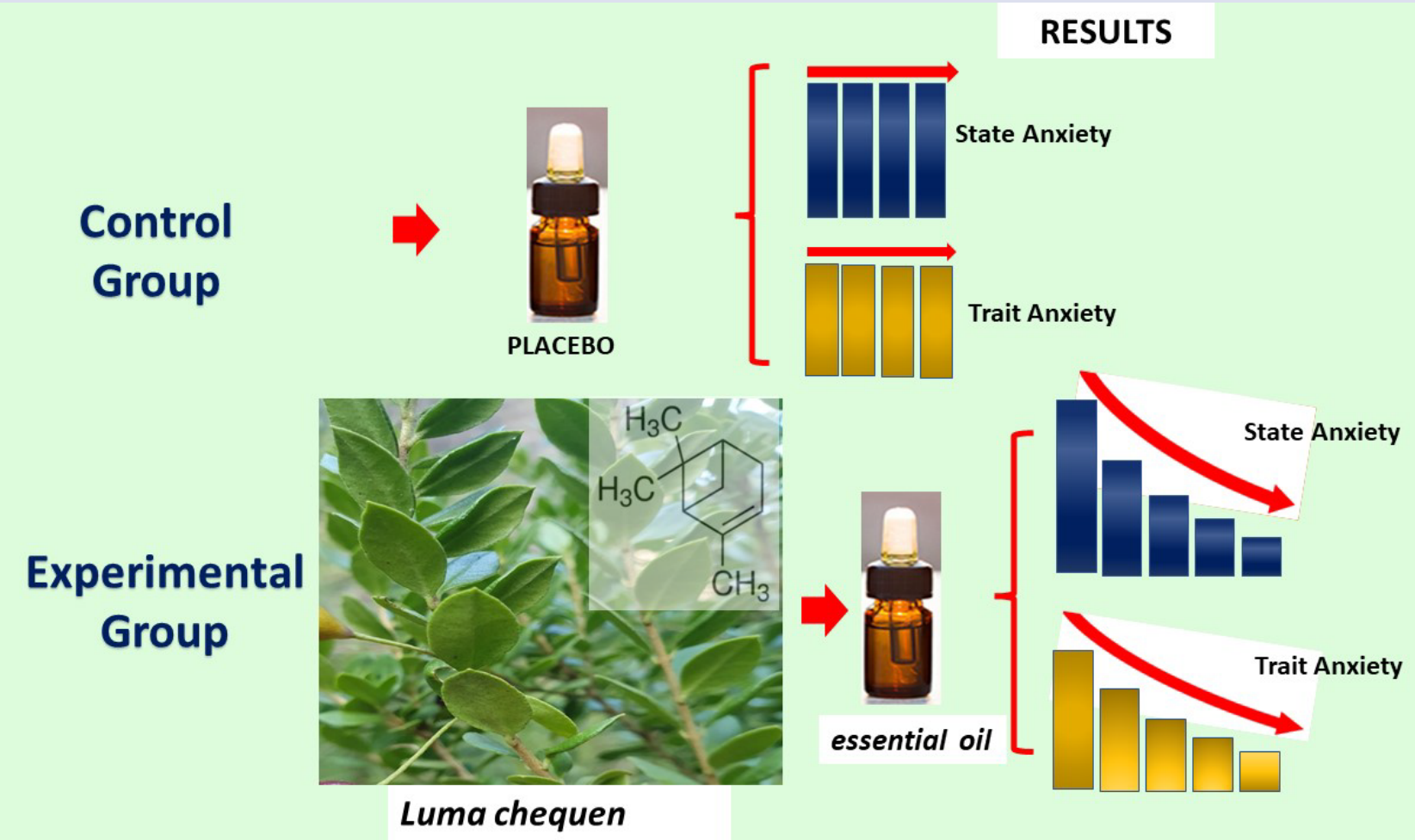




\section{ABOUT AUTHORS

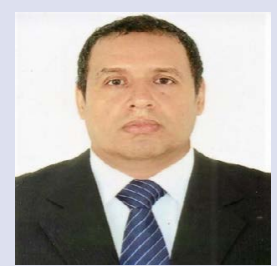 \\ Ms. Paul Alan Arkin Alvarado García \\ Master of Education. Professor at Universidad Autónoma del Perú. Develops research in Mental health problems, Complementary and Alternative Medicine, and natural products applicated to stress, anxiety, and depression.}

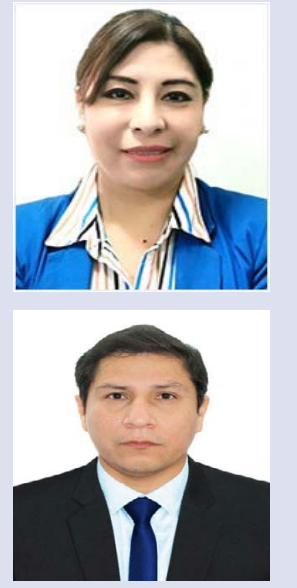

\section{Dra. Marilú Roxana Soto-Vásquez}

Doctor in Pharmacy and Biochemistry, professor of the chairs of pharmacognosy, phytochemistry, pharmaceutical botany of Faculty of Pharmacy and Biochemistry of Universidad Nacional de Trujillo. Develops Research in Natural Products with antiprotozoal, antitumor, antimicrobial activities, and Complementary and Alternative Medicine.

\section{Luis Enrique Rosales-Cerquin}

Gynecologist and obstetrics specialist. Professor at the Medicine School of Universidad César Vallejo. Develops research in reproductive health, natural products, and Integrative medicine.

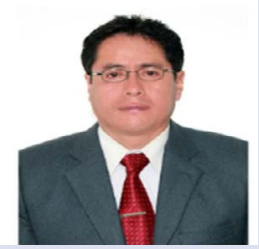

\section{Dr. Rafael Demetrio Jara-Aguilar}

Doctor in Pharmacy and Biochemistry, professor at National University of Trujillo, section Natural Products. Develops Research in Natural Products.

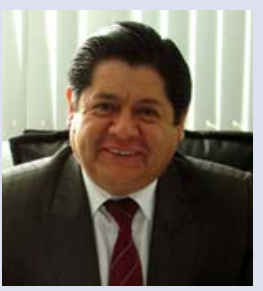

\section{Dr. Santiago M. Benites}

Doctor in Biomedical Science, Master in Science, researcher at Universidad Autónoma del Perú. Develops Research in Natural Products.

Cite this article: Alvarado-García PAA, Soto-Vásquez MR, Rosales-Cerquin LE, Jara-Aguilar DR, Benites SM. Anxiolytic-like Effect of Luma chequen Essential Oil: A Pilot Study. Pharmacogn J. 2021;13(6)Suppl: 1607-1613. 